\title{
Festas, disputas e mudanças políticas no Recife da época da Independência
}

Lídia Rafaela Nascimento dos Santos*

\begin{abstract}
RESUMO
Neste trabalho analisamos as festas cívicas do Recife na confluência dos estudos de história cultural e história política, colocando as festas no centro do debate. São analisadas as correspondências trocadas entre autoridades, os periódicos, os relatos de contemporâneos e de memorialistas sobre as funções sociais e políticas de tais festas entre os anos de 1820 e 1825 . Política, economia, religião e trabalho estão presentes nas festas. Elas foram diretamente influenciadas pelas peculiaridades do período estudado, especialmente pela independência, formação do Estado Nacional e pelas insurreições liberais. As expressões festivas, culturais $e$ políticas envolveram os esforços de diversos agentes sociais nas lutas por novos arranjos institucionais, especialmente pela independência do Brasil. Nesse período de intensas mudanças, as festas foram um dos meios utilizados para que as pessoas internalizassem a lealdade ao novo Estado. Evidenciamos as festas como espaço para demonstração de patriotismo, os preparativos para as festas, seus principais ritos, as formas de divertimento presentes nessas festas $e$ a constituições de novas identidades pelos diferentes grupos nessas ocasiões, no âmbito nacional $e$ local.
\end{abstract}

Palavras-chave: Festas. Independência. Festas cívicas.

\section{Festivities, disputes and political changes in Recife during the Independence period}

\begin{abstract}
In this work we analyze the civic celebrations in Recife at the confluence of studies of cultural history and political history, putting parties at the center of the debate. Its focus was on its social and political functions between the years 1820 and 1825 through correspondence analysis of the authorities, periodicals, reports of contemporaries and memorialists. Politics, economy, religion, work, everything is present at festivities. They were directly influenced by the peculiarities of the period studied, especially by the independence, formation of the National State and by the liberal insurrections. The festive, cultural and political expressions involved the efforts of various social agents in the struggle for new institutional arrangements, especially for the independence of Brazil. In this period of intense changes, the parties were one of the means used for people to experience change and internalize loyalty to the new state. We show the parties as a space to show patriotism, the preparations for the celebrations, their main rites, the forms of fun present in these parties and the constitutions of new identities built by the different groups on those occasions, nationally and locally.
\end{abstract}

Keywords: Festivities. Independence. Civic Festivities.

Artigo recebido em 16 fev. 2019.

\footnotetext{
* Bacharel, licenciada e mestra em História pela Universidade Federal de Pernambuco, doutora em história pela Universidade Federal Fluminense. Professora do Departamento de História e do Programa de Pós-Graduação em História da Universidade Católica de Pernambuco. E-mail: lidiarafaela@gmail.com.
} 
Aprovado em 17 abr. 2019.

As festas cívicas fizeram parte do processo que definiu a formação do Estado Nacional brasileiro. Festejar os momentos que significavam alguma vitória nesse emaranhado de interesses foi uma forma de mobilização política que demonstrava publicamente as escolhas da população do período. No Recife, os eventos que posteriormente se transformaram em marcos políticos da ruptura com a situação colonial foram festejados e vivenciados por todos: do mais eminente representante da coroa ao último escravo. Cada festeiro aproveitou as festas de acordo com os seus interesses, mas na profundidade de suas possibilidades.

A construção dos modos de festejar das províncias esteve intrinsecamente relacionada à sua forma de inserção nos projetos de nação nucleados no Rio de Janeiro. A participação de Pernambuco nesse processo foi marcada por muitas disputas. A década de 1820 se iniciou ainda sob as sombras da Insurreição Pernambucana. Desde a sua derrota, o rei manteve no comando da província o responsável pela repressão em 1817: o general Luís do Rego Barreto. Segundo Marcus Carvalho, ele "era um homem talhado para segurar as rédeas de uma província saída de uma revolta" (Carvalho, 1998, p. 2). Seu governo interferiu em variados aspectos da vida cotidiana em Pernambuco, inclusive no festejar.

O historiador pernambucano George Félix Cabral de Souza, analisando a documentação da Câmara do Recife, constatou que, nos anos seguintes à aclamação de Dom João VI, poucas datas foram festejadas na cidade. Foram encontrados apenas registros de 1820, da comemoração do aniversário e a aclamação de D. João VI com luminárias; além do nascimento do príncipe, com festas de máscaras (Souza, 2015, p. 389). As comemorações ligadas à vida da família real eram parte do governo real. Mesmo o mais rigoroso governador não podia se opor a elas.

Em momentos de dificuldades para a monarquia, era interessante festejar. Nas ocasiões relatadas acima, a população se reunia para comemorar as boas novas da família real em um período no qual o governo precisava de apoio, por, em data tão recente, ter repreendido a Revolução de 1817, ação dura que ficava na lembrança próxima dos sujeitos de Pernambuco. Como quase todo mundo se envolveu no acontecido, o medo e o rancor rondavam sempre pelas ruas e cabeças.

Como ressaltou Emília Viotti da Costa, o ano de 1820 começou com profundas mudanças no panorama político. Depois da Revolução Liberal eclodir na Espanha, ainda em janeiro, Dom João VI decretou uma série de medidas para tentar conter a propagação da 
revolução em Portugal (Costa, 1999, p. 42). Nem as festas, nem as decisões envolvendo política e economia foram suficientes para garantir que seus súditos não buscassem mudanças no governo.

A Cidade do Porto se sublevou em agosto, iniciando a Revolução Liberal que reinvidicava uma Constituição e a volta da Corte para Portugal. O movimento se espalhou rapidamente pelo território português. As notícias das novidades políticas em curso ocasionaram mudanças no Brasil. O Recife ficou em polvorosa. As dúvidas dos pernambucanos sobre os rumos que o reino tomava foram acompanhadas por teias conspiratórias por reformas na província. Havia, segundo Flávio Cabral, o boato de um levante, a estourar na quarta-feira de Cinzas, para derrubar o governador arbitrário (Cabral, 2008, p. 146).

Tal movimento possibilitou uma transformação importante nas formas de festejar em Portugal, que também se espalhou pelas áreas banhadas pelo Atlântico. Como afirma Jorge Crespo, antes da Revolução do Porto as festas faziam referência aos ritos de passagem da vida do soberano e de sua família; com as transformações constitucionais traziam consigo outras ideias e concepções de mundo, celebrando a "consagração da vida coletiva" (Crespo, 1990, p. 367-388). As festas cívicas, que exaltavam as atitudes que modificaram as formas de governo, encontraram um terreno fértil em Pernambuco, especialmente após a experiência do período de governo republicano da Revolução de 1817.

A primeira festa desse novo momento político em Pernambuco aconteceu em 26 de fevereiro de 1821, quando segundo Pereira da Costa, chegou ao Recife, a notícia da confirmação que D. João havia concordado em fazer o juramento da Constituição. Segundo seu relato, a cidade foi tomada por salvas, repiques de sino, vivas e um Te Deum na Matriz de Santo Antônio, uma das igrejas mais importantes da cidade, situada em um espaço de comércio bastante ativo e com um vai e vem de uma população altamente diversificada (Costa, 1962, p. 108-109).

A cerimônia em homenagem ao constitucionalismo que surgia no Império português reinstaurava um tipo de festa experimentado em solo pernambucano nos idos da Revolução de 1817. Como afirma Jorge Crespo, festejar esse juramento significava comemorar um novo mundo, "delineado pelas periferias onde os homens se encontravam por sua iniciativa $e$ responsabilidade" (Crespo, 1990, p. 375). As festas alcançaram popularidade no Recife. Além dos ritos oficiais, os constitucionalistas prepararam três dias de folgares e divertimentos que incluíram óperas, danças, cantorias, músicas, poesias, jantares. Pelo relato de Pereira da Costa, esses eventos teriam atraído a atenção de "todos os homens que, esquecidos de seus negócios e das arbitrariedades sofridas, só cuidaram de divertir-se" (Costa, 1962, p. 109). 
Motivos para tamanha diversão não faltavam. Mesmo sem enfrentar o governador carrasco, os constitucionalistas conseguiram uma vitória com o juramento da Constituição. O novo estatuto político decidido nas cortes de Lisboa transformou súditos em cidadãos, garantindo novos espaços para reivindicações. Além dessa mudança, para adequar os governos das províncias brasileiras às novas formas de organização política, foram organizadas juntas governativas provisórias para assumir o comando da província. Luís do Rego mostrou sua habilidade e conseguiu manter-se a frente da província convocando um Conselho Consultivo com pessoas por ele indicadas. Os constitucionais que esperavam assumir o governo da província ficaram de fora.

Uma decisão das Cortes de Lisboa foi extremamente importante para os rumos da política em Pernambuco. Como explica Flávio Cabral, entenderam que nenhum cidadão poderia ser perseguido por expressar sua opinião e que todos os desterrados por esse motivo tinham o direito de voltar para casa. A junta provisional da Bahia então reviu os processos de 1817 e absolveu "os réus do republicanismo" (Cabral, 2008, p. 153) que ainda não tinham sido perdoados em 1818: os líderes do movimento.

Manuel Joaquim de Menezes, cirurgião mor que combateu o movimento de 1817, contanos que a população do Recife reagiu com entusiasmo à notícia da liberdade dos líderes, trazida por um passageiro vindo da Corte, em 1821. Na mesma noite, colocaram luminárias e fizeram cortejos com bandas de músicas (Biblioteca Nacional, 182, p. 48). Rituais semelhantes às festas planejadas com antecedência: iluminação, cortejos e músicas. Quem sabe ao comemorar a soltura dos líderes da Insurreição de 1817, alguns possam até ter feito brindes com cachaça, em homenagem aos famosos brindes do período republicano, demonstrando apoio aos "pernambucanos" presos por suas lutas políticas.

Depois do regozijo com as notícias da decisão, foi a vez de receber festivamente os retornados. Em 26 de maio de 1821, os líderes de 1817 desembarcaram em Pernambuco. De acordo com o historiador Gilberto Vilar, foram recebidos com "cortejos, folganças, bandeirolas, discursos patrióticos e o solene Te Deum" (Vilar, 2004, p. 51). Havia pompa e circunstância dignas das entradas das autoridades nomeadas que chegavam à cidade para receber os líderes que combateram pelos interesses locais.

Segundo Pereira da Costa, o Te Deum foi celebrado alguns dias depois na Igreja do Carmo. A escolha dessa Igreja, localizada no Bairro de Santo Antônio, teria ocorrido porque o pároco da Matriz de Santo Antônio não quis cedê-la para essa celebração. Ressalta-se que, em 1817, o primeiro Te Deum para o novo Governo ${ }^{1}$ foi celebrado nessa Matriz e o pároco responsável por ela havia sido preso como um dos líderes da Revolução Pernambucana e era 
um dos regressos ao Recife pela anistia das Cortes. O rito religioso teria sido muito concorrido. Segundo Pereira da Costa "distribuíram 580 tochas, que não chegaram nem para a metade das pessoas que compareceram" (Costa, 1962, p. 145).

A chegada dos líderes rebeldes aumentou as tensões na província e Luís do Rego perdia cada vez mais o controle da Província. Várias reuniões secretas aconteciam, panfletos eram espalhados e alertavam ao Governador sobre os planos de luta que culminaram com a organização da junta provisória de Goiana. ${ }^{2}$

A Junta de Goiana governou em paralelo ao governo de Luís de Rego por quase dois meses. Após várias tentativas de conciliação, no início de outubro houve um acordo conhecido como Convenção de Beberibe, que reconhecia os dois governos nos territórios estabelecidos e previa a eleição de uma nova Junta de Governo, exigindo o retorno de Luís do Rego para Portugal. Em fins de outubro, houve a eleição. A escolha de governantes por uma decisão dos cidadãos locais, como analisa Dênis Bernardes, encerrava "uma longa história: a dominação do Antigo Regime em Pernambuco" (Bernardes, 2006, p. 397).

Uma Junta formada por pernambucanos assumiu o poder na província, tendo como presidente o comerciante Gervásio Pires. Em sua composição, de acordo com Maria do Socorro Ferraz Barbosa estavam três "liberais, participantes de uma forma ou outra dos conflitos com o absolutismo e sobreviventes da Revolução de 1817" (Barbosa, 2008, p. 114). Segundo Pereira da Costa, o General Luiz do Rego partiu para Portugal sem sequer esperar para dar posse a Junta (Costa, 1962, p. 170). Depois de anos no controle da província: o responsável pela repressão de 1817, o representante do poder absolutista de D. João VI finalmente foi expulso de Pernambuco, como analisa Maria do Socorro Ferraz Barbosa, por ter ficado sem apoio e sem elo na província (Barbosa, 2008, p. 104).

Essa rápida saída do General, segundo Pereira da Costa, teria inspirado a imaginação popular na criação de músicas e versos sobre o acontecimento, registrados em seu livro "Folclore Pernambucano." Cantar ou recitar eram práticas comuns para a população se divertir, divulgar um ideal ou ainda zombar de algumas autoridades durante as festividades do período. Em uma das versões coletadas, Pereira da Costa, sem indicar a origem dos versos, descreveu a situação em que eles foram cantados nos agitados dias de 1821.

Pereira da Costa relatou que, à época da partida de Luis do Rego, em uma roda de viola envolvendo pernambucanos e um português, foram cantados alguns versos das modinhas em voga na época dos festejos (Costa, 1907, p. 170). Podemos imaginar que muitos deviam se reunir para beber, conversar e se divertir nessas ocasiões. A presença de um músico numa roda 
de conversas animava a reunião e, aos goles das bebidas espirituosas, vários temas eram cantarolados.

Voltando aos versos cantados em 1821, em algum momento da roda um pernambucano se animou e cantou a seguinte quadra registrada, mesmo muito tempo depois, por Pereira da Costa: "Luis do Rego foi guerreiro,/Sete batalhas venceu/ Mas na oitava de Goiana/ Deu de gambias e correu" (Costa, 1907, p. 170). Por vivas e músicas a população mostrava o seu regozijo com o governo dos pernambucanos na província.

Além dessas manifestações de entusiasmo, se preparou um magnífico espetáculo para dar posse ao novo Governo, enquanto os absolutistas lamentavam a situação. Além do Te Deum, comumente usado no período para celebrar os novos governantes, os relatos destacam o regozijo público na organização de festas e divertimentos com a mudança no poder. $\mathrm{O}$ Segarrega, jornal ligado aos liberais, de 19 de dezembro de 1821 relatou que "a mocidade" organizou um baile em homenagem a Junta. O periódico o Relator Verdadeiro de 23 de dezembro de 1821, noticiou que militares e funcionários públicos adornaram a sala mais ampla do palácio para aproveitar com contradanças. Dias depois em 15 de dezembro eles repetiram os festejos no Teatro Público onde se cantou o Hino Constitucional Pernambucano.

Mesmo após eleita uma nova junta, jurada a Constituição e expulso o último governador régio da província, continuava a desordem. Um dos primeiros desafios da junta, como afirma Maria do Socorro Ferraz Barbosa, era restabelecer a ordem em Pernambuco. As tropas portuguesas e pernambucanas ainda estavam aquarteladas, a situação era caótica em assunto de organização militar, mesmo depois de organizarem a partida das tropas portuguesas, em fins de novembro (Barbosa, 2008, p. 115).

O constitucionalismo era motivo de disputas que tinham um amplo alcance social. Podemos ver tal situação relatada em um ofício do Alferes Jucélio Francisco de Paula Mesquita e Silva para o Presidente da Província, localizado na série Assuntos Militares, sobre uma disputa envolvendo algumas pessoas das camadas populares na Vila de Ipojuca, próxima a Recife, nos últimos dias do ano de 1821 em meio às festividades e sociabilidades comuns a esse período.

No mês de dezembro, a proximidade do Natal costumava intensificar o convívio social. A população se encontrava nas ruas, frequentava casas em reuniões privadas, ia para as cerimônias religiosas, etc. Entre as diversões, a complicada conjuntura do período era vivenciada nos festejos.

Pelo ofício escrito pelo Alferes Jucélio para a Presidência da província, em 30 de dezembro de 1821, Francisco Joaquim, acompanhado de alguns escravos, foi a um jantar no seu engenho. Enquanto aproveitavam a refeição, os senhores deram autorização para seus 
escravos circularem pela região. Os momentos de festas e sociabilidade dos proprietários, costumeiramente, possibilitavam momentos de liberdade para os cativos. O grupo dos escravos escolheu ir até uma povoação próxima, aproveitando para circular, talvez buscando encontrar outros companheiros, ir à venda, entre tantas outras possibilidades. Ao chegar na Vila de Ipojuca, encontraram um grupo cantando o Hino Constitucional e os viram ser repelidos pelo alferes Bezerra, com seus escravos e alguns forros. O grupo armado confrontou os festeiros e encerrou a reunião.

Ainda segundo o ofício do Alferes, nas noites seguintes o grudo do alferes Bezerra fazia rondas nos adros da Igreja de Ipojuca e Nossa Senhora do Ó para castigar quem cantasse o Hino Constitucional. Nessa época, se cantava vários hinos constitucionais pelo Brasil. Segundo o historiador Ilmar Mattos, eles anunciavam a constituição de um novo corpo político independente e possibilitava "à Brava Gente Brasileira a compreensão das experiências que alvoroçavam seus corações, naquele momento como o início de um tempo novo - uma revolução" (Mattos, 2005, p. 9). Em Pernambuco, um deles foi publicado no Jornal Relator Verdadeiro, de 23 de dezembro de 1821. Conhecido como hino constitucional pernambucano, ele fazia muito sucesso.

Arrastava Pernambuco/O mais pesado grilhão/ Quando despontou no Douro/ A lusa Constituição.

Enquanto aos pernambucanos/ Palpitar o coração/ Viverá em Pernambuco/ A Lusa Constituição.

Então mostra o Despotismo/ No rosto a perturbação/Vendo já brilhar no Tejo/ A Lusa Constituição.

Enquanto aos pernambucanos/Palpitar o coração/Viverá em Pernambuco/ A Lusa Constituição

Pesou mais na triste Olinda/Do tirano a férrea mão/ Quando o seu povo aderiu/ A Lusa Constituição.

Enquanto aos pernambucanos/ Palpitar o coração/ Viverá em Pernambuco/ A Lusa Constituição.

Enquanto o vil opressor/ Conspira contra a Nação/ Proclamam seus negros lábios/A Lusa Constituição.

Enquanto aos pernambucanos/Palpitar o coração/ Viverá em Pernambuco/ A Lusa Constituição.

Ele, o Monstro, classifica/ Em crime de alta traição/ A Liberdade, que oferece/ A Lusa Constituição.

Enquanto aos pernambucanos/ Palpitar o coração/ Viverá em Pernambuco/ A Lusa Constituição.

E querer independência/ Refletir contra a opressão/ Contra quem declarou guerra/ A Lusa Constituição.

Enquanto aos pernambucanos/ Palpitar o coração/ Viverá em Pernambuco/ A Lusa Constituição.

Que bens maiores teremos/Para nossa elevação,/Do que os bens que em nós derrama/ A Lusa Constituição.

Enquanto aos pernambucanos/Palpitar o coração/ Viverá em Pernambuco/ A Lusa Constituição.

Tiranos, desenganai-vos/Acabou-se a escravidão,/Reinará no Beberibe/ A Lusa Constituição.

Enquanto aos pernambucanos/ Palpitar o coração/ Viverá em Pernambuco/ A Lusa Constituição.

De Lisia a sorte se canta,/ Mas de Olinda porque não?/ E para os dois hemisférios/ A Lusa Constituição. 
Enquanto aos pernambucanos/ Palpitar o coração/ Viverá em Pernambuco/ A Lusa Constituição.

A letra desse hino fazia referência direta aos acontecimentos da luta dos liberais, exaltando a coragem e vontade dos pernambucanos em garantir um governo constitucional. Esses hinos eram muito usados no período para propagando dos novos ideais. As diversas saudações hínicas cantaroladas nas festas e espaços de sociabilidade eram indicativas do apoio do povo às transformações políticas em curso. Além de alcançarem popularidade, também se transformaram em motivos de disputas entre variados segmentos sociais, inclusive os homens comuns.

Os confrontos do fim do ano foram agravados no início do ano seguinte. Em primeiro de janeiro de 1822, os escravos Gaspar e José acompanharam o seu senhor, o alferes Jucélio, até o Hospício dos Franciscanos para que ele participasse das festividades que os frades organizaram para celebrar o ano bom, dia de grande gala no período. Enquanto os senhores estavam em um Te Deum dentro do templo, os escravos reunidos no seu adro também festejavam. Os escravos resolveram cantar o hino constitucional, dar vivas à Constituição e a El Rey, alguns mais empolgados também gritavam "morra os corcundas" (APEJE. Assuntos Militares 2, f. 124).

A festa dos escravos, que possivelmente também podia incluir alguns homens livres pobres naquele primeiro de janeiro, envolveu uma apropriação de um vocabulário político característico da disputa das elites. Talvez alguns desses cativos acreditasse que $\mathrm{o}$ constitucionalismo os beneficiaria de alguma forma. Para outros podia ser uma oportunidade de, em momentos de diversão, nos quais eram habitualmente vigiados, cantarem uma música que tinha entre seus versos a afirmação: "Acabou-se a escravidão". Apesar desta assertiva fazer referência à situação política da província, era apropriada de diferentes modos por quem os cantava. Ao cantar essas músicas, talvez estivessem articulando outras estratégias de luta pela liberdade.

O grupo liderado pelo alferes de Milícias João Carlos Bezerra, que andava vigiando os adros da igreja nos últimos dias do ano, apareceu com cinco escravos armados de bacamartes, pistolas e espadas e espancaram os cativos que festejavam a constituição. O Te Deum foi interrompido em meio à confusão. O senhor dos cativos lamentou no ofício enviado para a Junta governativa, que não conseguiu evitar a agressão e pedia providências (APEJE. Assuntos Militares 2, f. 124). Segundo Flávio Cabral, preocupada com tais exageros, a Junta proibiu todo tipo de divertimento na província, o que deve ter sido bem complicado, pois o início do ano era marcado por intensas festas (Cabral, 2008, p. 215). 
Tal interdição não significava que algumas datas não devessem ser festejadas. Por mais que as festas possibilitassem encontros que podiam acabar em conflitos, algumas também tinham um papel importante para a manutenção do poder e precisavam acontecer. Em 26 de janeiro de 1822 foi comemorado o aniversário de instalação das cortes, com grande parada, queima de fogos e outros entretenimentos (Cabral, 2008, p. 213).

Nos primeiros meses de 1822 também foi celebrado o nascimento da princesa Januária, com salvas e iluminação geral como comumente ocorria nessas festas em homenagem a família real. ${ }^{3}$ Em 13 de maio, uma atitude de corte do Marques de Angeja para comemorar o aniversário de D. João VI, gerou confusão pelas ruas da cidade. Ele teria entendido que era sua obrigação vestir-se como nas datas festivas oficiais com sua farda de camarista $e$ foi saudar o governador das armas (Drummond, 1885, p. 25-26).

Segundo o político oitocentista Antônio de Menezes Vasconcelos Drummond, a população já estava desconfiada do famoso maçom ${ }^{4}$ que estava na cidade esperando o reparo de seu navio que apresentou defeito em fins de abril 1822, em meio a uma viagem entre o Rio de Janeiro e Portugal. Ele teria desembarcado no Recife, com a marquesa e a filha do conde dos arcos e alguma criadagem. O conserto foi demorado e o povo da cidade começou a desconfiar dos motivos de sua presença.

A desconfiança atingiu seu auge com a atitude festiva do Marquês no dia do aniversário do Rei. Em pouco tempo, o quartel teria sido cercado por uma multidão, a maioria armada. A realização de um protesto com a comemoração do aniversário do Rei, uma festa comum nos regimes monárquicos, era uma atitude grave. Como afirma Iara Souza a população do Recife via "naquele ato de corte, uma traição", demonstrando insatisfação e oposição ao mando português. Tal episódio, segundo a historiadora, evidencia que festas oficiais propiciavam a demonstração da vontade do "povo" perante o soberano (Souza, 1999, p. 166-167), ainda que a posição dos pernambucanos fosse dúbia nesse período.

A escolha para formar um novo país com Dom Pedro a frente não era óbvia. Como afirma Marcus Carvalho, "às vésperas da Independência, as elites brasileiras, em cada uma das províncias, tinham escolhas a fazer. Foi em torno das alternativas possíveis que se constituíram as facções políticas em Pernambuco" (Carvalho, 1998, p. 332). No decorrer do ano de 1822, a Junta Governativa do Recife, presidida por Gervásio Pires, importante comerciante, senhor de engenho e um dos anistiados de 1817, havia afrontado as Cortes, sem declarar apoio ao projeto do Rio de Janeiro. A independência em Pernambuco foi um processo difícil, as revoltas e as disputas pela autonomia local tencionaram a adesão ao projeto centralista do Rio de Janeiro. 
A primeira festa a celebrar a nova situação política institucional foi, segundo o relato do Conselheiro Drummond, um ato solene que aconteceu em 1 de junho, reconhecendo Dom Pedro como regente (Drummond, 1885, p. 147). Em julho, segundo Flávio Cabral, chegou a notícia do título de Defensor perpétuo a Dom Pedro e a Câmara Municipal do Recife patrocinou os festejos (Cabral, 2008, p. 222-223).

Uma articulação política de José Bonifácio conseguiu derrubar a Junta de Governo que fazia forte oposição ao centralismo do Rio de Janeiro e, como enfatiza Marcus Carvalho, "garantiu a adesão de Pernambuco ao projeto de independência liderado por José Bonifácio" (Carvalho, 1998, p. 342). A nova Junta Governativa assumiu em fins de setembro o governo da Província. Era composta por donos de engenho da zona da mata e ficou conhecida por "junta dos matutos." Em outubro, organizaram um festejo pelo aniversário de Dom Pedro I, no dia 12 daquele mês, considerado dia de Grande Gala no Império português. Desta vez, celebrado com novos significados, comemorando um príncipe que tinha um papel importante na luta pela independência. Ainda sem saber que ele tinha sido aclamado em seu aniversário como Imperador no Rio de Janeiro em uma grande festa cívica.

Segundo a Gazeta Pernambucana de 9 de dezembro de 1822, pela manhã houve grande parada e à tarde um cortejo. Um grande concurso de gente foi à Câmara, onde se via o retrato do Regente a par do seu Pai. Segundo os vereadores, em ofício enviado para a Corte, a Câmara Municipal do Recife teria sido a única casa da província que realizou com pompa a inauguração do Retrato de D. Pedro I (Arquivo Nacional, 1973, p. 63).

Ainda segundo o periódico Gazeta Pernambucana de 9 de dezembro de 1822, Frei Miguel do Sacramento Lopes orou uma arenga mostrando a necessidade da "união Brasílica e sua independência política." Depois as tropas deram as descargas de costume, demonstrando de forma estrondosa para todos da cidade a importância desse dia. À noite, durante a apresentação teatral, foram levantados vivas ao Congresso Brasileiro e ao Regente Constitucional.

Mesmo sem celebrar a aclamação de um novo imperador, esse 12 de outubro em Recife foi festejado com ênfase nas mudanças que conduziam o Brasil a condição de Estado independente. Poucos dias depois os membros da Junta marcarem o "juramento cívico de adesão ao Sistema atual do Brasil" na Igreja Matriz no dia 17 de outubro (Arquivo Nacional, 1973 b, p. 692). A cerimônia de adesão contou com a presença das autoridades das Juntas Governativas, das tropas, dos membros da Câmara Municipal, do clero e dos cidadãos. Segundo Pereira da Costa, compareceram 1655 pessoas que juraram reconhecer e obedecer à Assembleia Brasileira Constituinte e Legislativa e defender a pátria, suas liberdades e direitos, até vencer ou morrer (Costa, 1962, p. 365). 
De acordo com o Assento da Casa de Relação, em 16 de novembro de 1822, a notícia da Aclamação chegou a bordo da escuna de guerra Maria Zeferina que vinha do Rio de Janeiro. ${ }^{5}$ (Arquivo Nacional, IJJ9 247 f.131). Pouco tempo depois, enquanto a Corte se preparava para a coroação, os membros da Câmara do Rio de Janeiro enviaram dois ofícios à do Recife cuja menção foi registrada no Livro de Vereação para que providenciassem a aclamação de Dom Pedro como "Imperador do Brasil o Sereníssimo Senhor Dom Pedro de Alcântara, regente e defensor Perpétuo do Brasil" (IAHGPE Livro das Vereações e acórdãos da Câmara do Recife 1817-1829 f. 114v).

Segundo a historiografia da independência, os festejos pela aclamação do Imperador pelo Brasil foram momentos chaves para a legitimação da Independência do Brasil, por caracterizar a irreversibilidade da ruptura e demonstrar apoio popular as decisões do soberano. Por isso foi importante que o ato fosse realizado em vários lugares do território do Brasil. Pernambuco, enquanto uma das principais províncias do Brasil e onde a adesão ao projeto de centralidade do Rio de Janeiro havia sido problemática, não podia ficar de fora dessas festividades.

As câmaras municipais tiveram papel importante na aclamação. Segundo lara Schiavinatto Souza, a vantagem de recorrer a essas instituições estava em sua antiguidade e por há bastante tempo serem responsáveis em nível local pela aplicação do poder institucional (Souza, 1999, p. 143). Na reunião da Câmara do Recife, os seus membros decidiram que a celebração seria realizada em 8 de dezembro na Igreja Matriz do Corpo Santo" (IAHGPE Livro das Vereações e acórdãos da Câmara do Recife 1817-1829 f. 113-114).

Pelo ofício enviado a Corte, a escolha foi por uma data já significativa no calendário social, por ser dedicada a Nossa Senhora da Conceição, padroeira do reino de Portugal, muito festejada no Brasil. Como explicaram os membros da Câmara Municipal, a virgem que protegia os exércitos e impérios também traria "todo o bem e perpetuidade para o nosso Império do Brasil" (Arquivo Nacional, 1973, p. 117).

De acordo com lara Schiavinatto, no século XIX era comum a estratégia de estabelecer uma coincidência entre celebrações cívicas e religiosas. "Havia um trânsito entre eles que reforçava mutuamente seus significados" (Schiavinatto, 2008, p. 18). Os festeiros que habitualmente celebravam a santa nas ruas da cidade, alguns dias antes foram avisados da dupla comemoração que transformaria por alguns dias as ruas do Recife em uma grande festa.

A Câmara Municipal do Recife enviou convites a diversas autoridades e informaram à "Junta dos matutos" que sairiam "em corporação no dia 7 de dezembro a anunciar ao Público a solenidade da Aclamação" (APEJE Câmaras Municipais 03. f.70). A decisão de proclamar a 
notícia em um bando foi uma importante estratégia para garantir o apoio da população ao ato. Segundo José Ramos Tinhorão, um bando servia como um "anunciador do espetáculo" (Tinhorão, 2000, p. 149). Era composto por uma comitiva de vereadores que saía pelas ruas, acompanhada por uma banda militar e um pregoeiro, responsável por ler o proclame em alguns locais da cidade. Desta forma, garantiam que muitos soubessem da festa extraordinária que estava para acontecer e fossem aclamar o imperador.

No dia 08 de dezembro de 1822, de acordo com termo de Aclamação, no Pátio da Casa da Câmara os vereadores proclamaram por três vezes os seguintes vivas: "Viva a nossa Santa Religião, Viva o Augusto Senhor Dom Pedro de Alcântara, $1^{\circ}$ Imperador Constitucional e Defensor Perpétuo do Brasil." No termo, registra-se que compareceram o Juiz de Fora, os membros da Câmara Municipal, a Junta Provisória, o Governador das Armas, os componentes do Tribunal da Relação, o clero, a nobreza e o "Povo", os homens bons e "mais cidadãos de todas as classes civis e militares." (IAHGPE Livro das Vereações e acórdãos da Câmara do Recife 1817-1829. f.115 v e 116).

Há registros que além do rito na casa da câmara também se festejou na Igreja do Corpo Santo. Frei Caneca foi o responsável pela oração do Te Deum (Costa, 1962, p. 366). Mesmo inicialmente não apoiando a adesão ao projeto do Rio de Janeiro, ele foi escolhido pelos organizadores da festa para tão importante função. Segundo Luiz Geraldo da Silva, esse ato foi o símbolo da "adesão dos federalistas ao "projeto do Rio de Janeiro." ${ }^{6} \mathrm{Em}$ seu discurso, o clérigo ressaltou a união do temporal e do religioso, enlaçando os dois motivos da festa do dia. Destacando que a celebração deveria servir para preconizar felicidade da nação e fazer com que "os outros se encham de alegria festiva e transcendente" (Caneca, apud Mello, 2001, p. 105).

A imagem que se quis passar foi a do comparecimento dos cidadãos para ratificar um dos atos fundadores do novo Estado Nação. Por se tratar de um documento que visava passar imagem de unidade, não há registro de oposição a tal ato. Mas no livro de Registro de Ofícios da Junta, fica evidente que as disputas eram um problema na cidade, tanto que havia uma ordem que proibia o uso de fogos de artifício em prol da defesa do país (APEJE, Registro de Ofícios 9/1 f. 251).

A regra foi suspensa para que a festa da aclamação acontecesse com a grandeza necessária, entre os dias 7 a 10 de dezembro de 1822. Sem fogo artificial, os festejos não estavam completos no Recife Oitocentista. Tal decisão demonstra que a festa deve ter sido bem mais ampla que os registros oficiais encontrados na documentação. Nesses dias, é provável que diversos divertimentos tenham ocorrido, tais como jantares, cortejos pelas ruas, contradanças, apresentações teatrais, cavalhadas. Com as ruas animadas, iluminadas e o céu adornado pelo 
brilho glamouroso dos fogos. As pessoas das diferentes classes aproveitavam a junção da festa sagrada com a cívica e festejaram com as esperanças renovadas com a nova situação política do Brasil.

Recife não era a capital da província nesse período, mas os membros da sua Câmara Municipal buscaram estabelecer o papel de liderança em Pernambuco na causa da independência. Os vereadores da Câmara do Recife reivindicaram através de um ofício a primazia na realização de festas pela independência na província em 1822 . Os vereadores da cidade buscaram convencer que, com o empenho na solenidade de Aclamação na cidade, inspiraram as outras Câmaras da Província, "que cheias dos mais nobres transportes se inflamaram de sorte, que uniformes abraçaram tão justa, como interessante causa" (Arquivo Nacional, 1973, p. 63).

As autoridades do Recife, ao enviarem ofícios sobre as festividades realizadas, buscavam garantir o uso dessas festas como forma de demonstrar a legitimidade nas regióes onde atuavam. Parte da motivação para os gastos e empenho com as festas cívicas era o interesse das autoridades locais em mostrar à Corte o seu envolvimento no processo de consolidação da nova condição institucional do Brasil. Afinal, em algumas ocasiões o fazer crer é tão importante quando o fazer. A unidade territorial do Brasil era frágil nesse período. Não existia um único sentimento de nacionalidade ou a noção de pertencimento a mesma estrutura, ainda que existissem tentativas de afirmação de uma identidade nacional, como afirma Marco Morel (2005, p. 154).

A junta governativa também reivindicou para si o crédito pela inspiração das festividades organizadas pelas outras Câmaras Municipais da Província. Em ofício enviado a José Bonifácio, os seus membros afirmaram que expediram ordens para que também se aclamasse o Imperador em Olinda e outras vilas. Informaram, ainda, que as festividades ocorreram sob a ameaça de um bloqueio de alguns navios por ordem do Brigadeiro Madeira, que estava atrapalhando o comércio e a comunicação com a Corte (Arquivo Nacional IJJ 9247 f.150).

Passadas as festividades, a província ainda estava envolta em conflitos, especialmente devido às ações de Pedro Pedroso. Militar conhecido na cidade, pelo menos desde 1817 era responsável por vários sucessos durante o governo revolucionário e, desde setembro de 1822 , exercia a função de Governador das armas. De acordo com Marcus Carvalho, tinha grande apoio da tropa e estava desafiando o poder da Junta (Carvalho, 1998, p. 6). ${ }^{7}$ O apoio da tropa e do "povo" ao governador das armas foi relatado pelo periódico Gazeta Pernambucana como fonte de inúmeros problemas e distúrbios, alguns envolvendo os festejos. Um deles aconteceu em 22 de janeiro de 1823, nas comemorações do aniversário da Imperatriz. ${ }^{8}$ Pelo relato, 
publicado no periódico Gazeta Pernambucana de 25 de março de 1823, houve uma Grande Parada, que, segundo o periódico, contou com a presença de uma "multidão de gente mais vil".

Por mais que no início da década as "festas constitucionais" tenham ganhado força, a opção por uma monarquia exigia a manutenção das festas em homenagem a família real. Segundo o mesmo número do periódico Gazeta Pernambucana, depois do Presidente da "Junta dos Matutos" ter dado Vivas ao Imperador e sua consorte, o povo respondia com "Viva Pedroso, nosso Governador das Armas! que correspondia com mil cortejos." Mesmo sem o periódico fazer referência a presença das elites, muitos membros da aristocracia pernambucana também deviam estar lá, talvez alguns também o apoiassem. Como afirma Marcelo Mac Cord, Pedro Pedroso "não teria ascendido sem a proteção de grupos da elite e sem o temor de alguns de seus adversários não brancos" (Mac Cord, 2005, p. 199).

Ao saudar um militar que estava desafiando a autoridade da Junta, como destaca a historiadora Carla Simone Chamon para atitudes semelhantes em Minas Gerais, o "povo" deixava claro que "não estava ali apenas para receber passivamente a mensagem do poder" (Chamon, 1998, p. 192). Muito além de cumprir com o papel geralmente destacado nos documentos sobre as festividades: o fervor público, a parcela da população que se fez presente nesse festejo, resolveu usar o seu entusiasmo para demonstrar o apoio a Pedroso em um dia de festa oficial organizada pela Junta de Governo.

Na festa da Restauração Pernambucana dos holandeses, em fevereiro de 1823, Pedro Pedroso estava em uma das palhoças, rodeado de pretos e pardos, comendo, bebendo e ouvindo música com uma negra sentada no colo (Silva, 2003, p. 518). No Recife, em tempos de festas, se construíam mocambos de palha nas proximidades, que serviam como espaços para músicas, danças, bebedeiras e outros divertimentos (IAHGPE. Atas da Câmara do Recife, Livro 75. f. 23) Semelhante ao que Martha Abreu destaca para a festa do divino no Rio de Janeiro, era ali onde ocorria a diversão preferida do "povo" (Abreu, 1999, p. 71-72).

Pedroso aproveitava o momento da festa para se divertir, e ao ver as autoridades da província passando, as convidou para se juntar a eles, como afirma Marcus Carvalho, naquele "insólito convite a donos de terra e gente, teria dito: - Sempre estimei muito esta cor, é a minha gente" (Carvalho, 1998, p. 6). Como bem analisa Luiz Geraldo Silva, Pedroso "não apenas parecia um hábil manipulador de identidades políticas, mas também de identidades raciais" (Silva, 2003, p. 517).

Para além das escolhas de onde aproveitar os festejos, o militar articulou suas identidades múltiplas e cambiantes para tomar o poder na província. Em fevereiro, eclodiu uma sedição contra a Junta de Governo liderada por Pedro Pedroso que conseguiu tomar o controle 
da cidade do Recife. Segundo o periódico A Gazeta Pernambucana, de 25 de março de 1823, ele "estabeleceu e sustentou por nove dias uma República Democrática." Depois que Pedroso foi derrotado, outro momento de registros de festejos na documentação do governo provincial foi em julho com a "restauração da Bahia".

Um ofício da Junta do Governo solicitou que a Fazenda liberasse cera para que os tribunais participassem da iluminação de três dias que se faria na cidade pela "restauração da Bahia" (APEJE Registro de Provisões 8.1 f.92v). Segundo o periódico a Gazeta Pernambucana, de 14 de agosto de 1823, além dos ritos oficiais, várias casas organizaram jantares e "outras demonstrações de alegria." Alguns dias depois das comemorações oficiais pela independência da Bahia, no dia 19 de julho, a "Mocidade" de Pernambuco pediu licença para fazer um enterramento simbólico do General Madeira, responsável pela campanha portuguesa na disputa pela independência da Bahia. Provavelmente nessas festas coletivas não oficiais da juventude, como afirma Michel Vovelle, apareciam as contestações e tensões com mais amplitude (Vovelle, 1976, p. 25).

Nos casos analisados pela historiografia, os enterramentos aconteceriam para celebrar o fim de um governo ruim. Como afirma João José Reis o funeral sem morte era um ritual político e subversivo (Reis, 1991, p. 165-166). Pela descrição da Gazeta Pernambucana de 14 de agosto de 1823, a frente do cortejo iam homens vestidos de padres, de sobrepeliz e barrete levando archotes acesos nas mãos. Às vestes eclesiásticas somavam-se duas alas com pessoas carregando cereais, vassoura, um abano e uma panela de fogo com que queimavam alcatrão, seguidos de um falso Padre Gordo com grandes óculos e livro.

Em vez de rezar, todos repetiam palavras de despedidas com zombarias que enfatizavam que Portugal não era capaz de dominar sequer uma província do Brasil. Esse cortejo foi acompanhado por uma grande parte da população e por uma música do segundo Batalhão que tocava marchas fúnebres. Passaram pela porta de várias pessoas simulando o ritual dos sepultamentos verdadeiros e, por fim, enforcaram a esquife do general proferindo uma oração fúnebre citando os crimes dos lusitanos.

Segundo o periódico A Sentinela Da Liberdade na Guarita de Pernambuco, em 9 de agosto de 1823 chegou em uma fragata francesa a notícia da troca do ministério, ocorrida em 17 de julho. Muitos teriam festejado na cidade de forma espontânea, criando "um efeito admirável nesta Capital de Pernambuco." Os três bairros centrais da cidade receberam iluminação especial no mesmo dia, o povo animava o espetáculo visual com vivas e aplausos que irrompiam a noite festiva, que no entender do editor eram um sinal de "demonstrações do júbilo em que nadavam os corações." 
A mocidade mais empolgada teria formado um cortejo com música e archotes pelas ruas da cidade em um espetáculo acompanhado por mais de 400 pessoas, entre as quais o editor destacava a presença de "gente de todas as ordens." Tal destaque é um importante indicativo da amplitude do alcance social que algumas notícias políticas alcançavam na mobilização da população para festejar naqueles tempos de redefinição do poder. Toda essa gente animava ainda mais a noite, com um dos grandes símbolos do regozijo dos festejos oitocentistas: os foguetes de ar. O editor afirmava que soltavam os fogos abrilhantando o espetáculo, depois gritavam por entre aplausos: "Viva o Imperador Constitucional Liberal! Viva o Soberano Onipotente Congresso do Brasil! Viva a Constituição! Morra o Apostolado! etc."

Para o editor, essa era uma demonstração pública de como a província sofria nas mãos do antigo ministério. Pela descrição, rapidamente a população conseguiu preparar a cidade e se reunir para festejar uma notícia que era motivo de regozijo para os liberais pernambucanos. Em outubro, pouco antes do aniversário da aclamação, o Governo recebera notícias da "restauração do Maranhão." A população comemorou com muito júbilo o que, segundo o relato enviado à Corte pela Junta, se percebia "nos semblantes de todos, procedido da Solenidade do Dia e aumentado por aquela notícia tão satisfatória" (Biblioteca Nacional, 1824, não p.).

As tensões em Pernambuco aumentaram com as atitudes de Dom Pedro em fins de 1823: dissolução da Assembleia Constituinte, instituição da presidência de província e medidas contra a liberdade de imprensa. O Comandante de Armas relatou, em ofício enviado em fevereiro de 1824 ao Ministro de Guerra, alguns dos problemas que ocorriam na província, entre eles a desobediência de parte das tropas, mas que a província estava em paz. Depois de exaltar sua ação estratégica na condução do controle da província, relata que descobriu que na Corte eram espalhados boatos a seu respeito. Era acusado de ter se desfeito de uma insígnia oficial da ordem do cruzeiro, instituída em dezembro de 1822 (Arquivo Nacional Caixa 613 não p.).

Para desfazer o mal-entendido, escreveu em seu ofício que não era visto cotidianamente com a insígnia, pois apenas a usava em dias de gala ou representação, como os outros cidadãos. Apontando como testemunho que o fez em duas importantes festas ocorridas no início de 1824 , o aniversário da Imperatriz e a restauração dos holandeses, sem fazer menção a confusões nessas festas, mesmo a cidade já estando com os ânimos exaltados com as atitudes de Dom Pedro, principalmente com relação a constituição.

Em 1824 as tensões aumentaram com a recusa dos pernambucanos em aceitar a nomeação do primeiro presidente da província, Francisco Paes Barreto. Em julho, foi deflagrada a Confederação do Equador, um movimento que lutou contra os exageros de poder e que entre 
julho e setembro conseguiu tomar a cidade e instaurar um novo governo, que tinha entre seus líderes participantes ativos de 1817, como Manoel de Carvalho Paes de Andrade e Frei Caneca.

Infelizmente, na documentação pesquisada, há pouco sobre o uso da festa pelos rebeldes. Sabemos pelo relato de José de Barros Falcão de Lacerda (responsável pela expedição que derrotou o movimento em 12 de setembro de 1824) que ao menos as festas religiosas aconteciam com a iminência da chegada da repressão. Ele escreveu que uma das coisas que garantiram o sucesso da sua empreitada foi o fator surpresa. Pois, em consequência de uma festa religiosa que acontecia em Recife, acompanhada de muito barulho e repiques de sinos, os confederados ignoraram a marcha do Exército até que eles chegassem ao bairro de Afogados, perto demais dos bairros centrais para que eles conseguissem organizar uma defesa (Biblioteca Nacional, 182-, p. 6).

Segundo o ofício do governador de Pernambuco, Francisco de Lima e Silva, após a derrota da Confederação do Equador, em 18 do setembro de 1824, se celebrou um Te Deum. Ele também deu ordens para que se iluminasse a cidade por três dias e enviou um ofício ao Comandante Interino da Esquadra surta no Lameirão David Jovvett. As ordens determinavam que, para que o ato fosse mais solene, fosse dada uma salva de 101 tiros pelas embarcações da divisão do seu comando e pelas Fortalezas da Cidade (APEJE Ofícios do Governo 25 f.25 v e 26.).

Além das comemorações pelo fim da Confederação do Equador, em setembro o presidente da província também organizou festejos em honra do reconhecimento da independência pelos Estados Unidos da América, primeiro país a reconhecer a nova situação institucional, especialmente frente ao posicionamento da Santa Aliança de não aceitação da independência das ex-colônias. O presidente da província enviou ofícios em 25 de setembro de 1824 convidando os oficiais e publicou um bando para garantir a presença do povo nas "públicas demonstrações de contentamento" a se realizarem no Palácio do Governo (APEJE Ofícios do Governo 25 f.4 v e 5).

No livro de Registros da Câmara de Olinda há um ofício recebido da Câmara Municipal do Recife em 26 de novembro de 1824, convidando os membros para festejar o aniversário da coroação do Imperador e fazer o juramento da Constituição em 1 de dezembro. Nesse mesmo livro também registraram um edital onde eram convidava todas "as Autoridades e Cidadãos de todas as classes" a Sala do Palácio do Governo no dia $1^{\circ}$ de dezembro, de onde partiram até a Igreja Matriz de Santo Antônio para prestar juramento ao "novo pacto de aliança que há de consolidar a estabilidade do trono imperial e firmar para o sempre a glória da nação brasileira" (APEJE. Diversos III- 12 f. 250 e 251). 
Cada conquista que ajudasse a consolidar a nova situação do Brasil precisava ser comemorada e deveria servir para reforçar a unidade ainda não consolidada, seja no cenário externo ou mesmo no interno. Os vereadores de Olinda enviaram um ofício para a Câmara do Recife no dia 27 de novembro, no qual se desculpavam por não poder comparecer ao ato, pois o estandarte não estava pronto e julgavam que não podiam "se apresentar com indignidade em uma tão pomposa função" (APEJE. Diversos III- 12 f.251 v e 252). Para o governador da província era essencial que os representantes das principais Câmaras Municipais estivessem juntos no juramento e ordenou por ofício de 27 de novembro que fossem com as armas do Senado (APEJE. Diversos III- 12 f.252). Após a Confederação do Equador, era ainda mais importante que autoridades e cidadãos se mostrassem unidos para esse ato solene de demonstração de fidelidade ao Império, ao jurarem a Constituição.

Em um clima de paz aparente, segundo Samuel Campelo, no Natal de 1824 os oficiais da expedição pacificadora decidiram promover espetáculos teatrais para celebrar tão importante data cristã. Como os atores saíram da cidade devido ao conflito, foi necessário dar um salvo conduto para um ator que foi sargento dos confederados (Campelo, 1924, p. 386-388).

Logo no início de 1825, o governador da província convidou, por um ofício, os membros do Senado e os funcionários da Câmara para aplaudirem o dia do Fico ( 9 de janeiro) com solenidade e pompa (IAHGPE Livros ofícios da presidência 1824-1829). Alguns dias depois, em 13 de janeiro, foi o dia da execução de Frei Joaquim do Amor Divino Caneca, um dos principais líderes da Confederação do Equador, transformando-se em um grandioso espetáculo público, ${ }^{\dagger}$ demonstrando a força do Estado Nacional.

Após esse momento inicial de rigorosas punições, estando assegurada a derrota do movimento, a população local precisava esquecer os problemas ocasionados pelo tempo de conflito armado: carestia, violência, restrições das liberdades, espetáculos punitivos entre outros. Em fevereiro, foi noticiado por fontes não oficiais o reconhecimento português da independência e a província se encheu de demonstrações de regozijo.

O Senado da Câmara do Recife escreveu para o Imperador informando do júbilo que se instaurou na província, ressaltando a sua contribuição para o sucesso da causa da independência e integridade do Império e aproveitou a ocasião festiva para intervir a favor dos envolvidos na Confederação. Segundo os vereadores, "enquanto a Província exulta por tal motivo de Festa Nacional, ainda existe uma parte dela que geme temerosa de ver alçado sobre

\footnotetext{
† No dia 13 de janeiro de 1825 deixou o oratório para o cumprimento de sua sentença de morte. Seguiu para a execução em um cortejo que durou mais de uma hora, e passou por importantes ruas da cidade, como a Rua do Crespo, Rua do Queimado, Rua do Livramento, Rua Direita. Ainda teve que participar da cerimônia de degradação e depois as recusas dos algozes, até a sua execução por fuzilamento. O povo lotou as ruas da cidade, segundo Gilberto Vilar uns choravam outros aplaudiam a vitória do Imperador. Ver: Vilar, 2004 e Morel, 2000.
} 
suas cabeças o formidável cutelo da justiça punitiva." O despacho do ministro ressaltava que o Imperador não podia receber as felicitações da Câmara por não ter notícias oficiais do reconhecimento, mas ressaltava que o Imperador estava usando da sua clemência com os criminosos (Arquivo Nacional, IJJ 9614 não p.).

No final do ano, o Tratado de Reconhecimento da Independência foi comemorado pelas Câmaras Municipais de Recife e Olinda. Em 05 de novembro, os membros da Câmara do Recife convidaram, por ofício, os membros da Câmara de Olinda para comparecerem às festividades programadas para ocorrerem entre os dias 13 e 15, na Igreja do Corpo Santo, "pelo feliz reconhecimento do Brasil à categoria de Império Independente." Em 8 de novembro, os membros do Senado de Olinda aceitaram tal convite, e chamaram os membros da Câmara do Recife para as que organizariam com o mesmo motivo entre os dias 10 e 12 (APEJE Diversos III11 f.37). Somando as festas das duas Câmaras, foram seis dias de comemorações. Segundo Antero José Ferreira de Brito, Governador de Armas em ofício enviado para o ministro de guerra foram dias de grande regozijo (Arquivo Nacional Caixa 742 não p.). Como as cidades eram muito próximas, os festeiros mais empolgados podem ter aproveitado todos esses dias de patriotismo e diversão.

Na década de 1820, as festas foram um caminho para a consolidação das novas fases de poder. Não parou de ter festa desde 1820 até 1825, mesmo nos períodos mais críticos da consolidação do Estado. Tudo o que estava acontecendo era refletido num processo festivo, na rua e nas igrejas. O "povo" reconhecia a festa ao seu modo e os senhores de engenho, escravos, comerciantes, padres, autoridades, cada um no seu limite aproveitou e usou as festas para apoiar os seus interesses.

\section{Referências}

ABREU, Martha. O Império do Divino: jestas religiosas e cultura popular no Rio de Janeiro, 1830-1900. Rio de Janeiro: Nova Fronteira; São Paulo: FAPESP, 1999.

ARQUIVO NACIONAL. As Câmaras Municipais e a Independência. Rio de Janeiro. Conselho Federal de Cultura e Arquivo Nacional vol.1, 1973.

ARQUIVO NACIONAL. As juntas governativas e a Independência. Rio de Janeiro. Arquivo Nacional, Conselho Federal de Cultura, 1973b. 
BARATA, Alexandre Mansur. Maçonaria, sociabilidade ilustrada e Independência do Brasil (1790-1822). Juiz de Fora: Ed. da UFJF; São Paulo: Annablume, 2006.

BARBOSA, Maria do Socorro Ferraz. Liberais constitucionalistas entre dois centros de poder: Rio de Janeiro e Lisboa. Tempo, Niterói, v. 12, n. 24, 2008, p. 98-125.

BERNARDES, Denis Antônio de Mendonça. O patriotismo constitucional: Pernambuco, 1820-1822. São Paulo: Hucitec/Fapesp; Recife: UFPE, 2006.

BIBLIOTECA NACIONAL Documentos relativos aos acontecimentos revolucionários e outros objetos da Província de Pernambuco dos anos de 1823 e 1824 [Manuscrito] Assina Paes Barreto, Francisco de Paula Cavalcanti de Albuquerque e Manoel Beserra de Mello.

CABRAL, Flávio José Gomes. Conversas reservadas: Vozes públicas, conflitos políticos e rebeliões em Pernambuco no tempo da independência do Brasil Universidade Federal de Pernambuco, 2008.

CAMPELO, Samuel. O Teatro em 1824 in: Revista do LAHGPE, vol 26, 1924.

CANECA, Frei. Sermão da Aclamação de D. Pedro I [Na solenidade da aclamação de d. Pedro d'Alcântara em primeiro imperador do Brasil mandada celebrar pelo Senado da cidade do Recife a 8 de dezembro de 1822, na Matriz do Corpo Santo com assistência da Junta Provisódia, Relação, Nobreza e Povo]. In: MELLO, Evaldo Cabral de (org.). Frei Joaquim do Amor Divino Caneca. São Paulo: Editora 34, 2001.

CARVALHO, Marcus J. M. de Cavalcantis e cavalgados: a formação das alianças políticas em Pernambuco, 1817-1824. Revista Brasileira de História, São Paulo, vol. 18, n. 36, 1998, p. 331-366.

CARVALHO, Marcus Rumores e Rebeliões: estratégias de resistência escrava no Recife, 1817-1848. Tempo vol 3, nº, Rio de Janeiro, 1998.

CHAMON, Carla Simone O Cenário da Festa. Festa Cívica em Minas Gerais no século XIX. Varia História, Belo Horizonte, n. 19, 1998, p. 183-204.

COSTA, Emília Viotti da. Da monarquia a república: momentos decisivos. 6 ed. São Paulo: Fundação Editora da UNESP, 1999.

COSTA, F.A. Folclore Pernambucano. Revista do Instituto e Geográfico Brasileiro, Tomo LXX parte II. Rio de Janeiro: Imprensa Nacional, 1907.

COSTA, F.A. Pereira da. Anais Pernambucanos Recife: Arquivo Público Estadual, 1962, vol. 8. 
CRESPO, Jorge. A história do Corpo. Lisboa: Difel: Difusão Editorial, 1990.

DRUMMOND, Vasconcelos (A. de M.) - Anotações de A M Drumond a sua biografia Memórias, vol. 13 dos Anais da Bib. Nacional, 1885.

MAC CORD, Marcelo. O Rosário de D. Antônio: irmandades negras, alianças e conflitos na história social do Recife, 1848-1872. Recife: Ed. Universitária da UFPE, 2005.

MATTOS, Ilmar Rohloff de. Construtores e herdeiros: a trama dos interesses na construção da unidade política. Almanack Braziliense, [S.1.], n. 1, 2005, p. 08-26.

MENEZES, Manoel Joaquim de. História médica brasileira e da Revolução de Pernambuco em 1824.182-. [manuscrito].

MORAIS, A.J. Melo. A independência e o Império do Brasii. Brasília: Senado Federal, 2004.

MOREL, Marco. As transformaçôes dos espaços públicos: imprensa, atores políticos e sociabilidades na cidade imperial (1820 - 1840). 1. ed. São Paulo: Hucitec, 2005.

MOREL, Marco. Frei Caneca: entre Marília e a pátria Rio de Janeiro: FGV, 2000.

REIS, João José. A morte é uma festa ritos fúnebres e revolta popular no Brasil do século XIX. São Paulo: Companhia das Letras, 1991.

SANTOS, Lídia Rafaela Nascimento dos. Das festas aos botequins: organização e controle dos divertimentos no Recife (1822-1850). Dissertação (Mestrado em História). Recife, Universidade Federal de Pernambuco, 2011.

SCHIAVINATTO, Iara Lis. Entre os manuscritos e os impressos. In: LEITE, Monica; FONSECA, Silvia C. P. de B. (orgs.). Entre a Monarquia e a República. Imprensa, pensamento político e historiografia. 1822-1889. Rio de Janeiro: UERJ, 2008, p. 13-33.

SILVA, Luiz Geraldo. Negros patriotas. Raça e identidade social na formação do Estado nação (Pernambuco, 1770-1830). In: ANCSÓ, István (org.). Brasil: formação do Estado e da Nação. São Paulo: Hucitec; Unijuí; FAPESP, 2003, p. 497-520.

SILVA, Luiz Geraldo. Um projeto para a nação: Tensões e intenções políticas nas "províncias do Norte" (18171824). Revista de História, São Paulo, n. 158, 2008, p. 199-216.

SOUZA, George F. Cabral de. Elites e exercicio de poder no Brasil colonial: a Câmara Municipal do Recife 17101822. Recife: Editora UFPE, 2015. 
SOUZA, Iara Lis Franco Schiavinatto Carvalho. Pátria coroada: o Brasil como corpo político autônomo 1780-1831. São Paulo: UNESP, 1999.

TAVARES, Francisco Muniz. História da Revolução de Pernambuco em 1817. Recife, Tipografia Industrial, 1884.

TINHORÃO, José Ramos. As festas no Brasil Colonial. São Paulo: Ed. 34. 2000.

VILAR, Gilberto. Frei Caneca: gesta da liberdade 1799-1825. Rio de Janeiro, Mauad, 2004.

VOVELLE, Michel. Les Metamorphoses de La fête em Provence de 1750 a 1820. Paris: Aubier/Flammarion, 1976.

${ }^{1}$ De acordo com a narrativa de Francisco Muniz Tavares, ao terceiro dia do movimento o Padre Luiz Jose de Albuquerque, vigário da Freguesia de Santo Antônio, mandou cantar um solene Te Deum em ação de graças ao novo governo (Tavares, 1884, p. 53). Os líderes do movimento souberam ressignificar um rito festivo usado para celebrar a monarquia para valorizar um novo pacto político. Dotar esse rito tradicional de um novo significado demonstra uma estratégia comum no período: aproveitar costumes correntes para celebrar novos arranjos de poder.

${ }^{2}$ Goiana era um polo algodoeiro e açucareiro, o segundo maior núcleo urbano da província e tinha fácil acesso ao interior.

${ }^{3}$ A junta provisória preocupou-se em afirmar a Dom Pedro que todos os pernambucanos se alegravam com o evento que suavizava e mitigava a multidão de males que o Brasil sofria. O Deão Bernardo Luís Ferreira Portugal e o Chantre Jerônimo Paz dos Santos enviaram felicitações ao Imperador do júbilo, mas afirmavam ser em benefício da Nação Portuguesa. A ênfase na festa ser benéfica ao Brasil ou a Nação Portuguesa é uma distinção importante nesse ano, em que a união do Reino Unido estava por um fio (Arquivo Nacional IJJ 9246 não paginado).

${ }^{4}$ Após a violenta perseguição aos Maçons em 1817, confessou-se maçom e como arrependimento ofertou sua prata para a urgência do Estado (Barata, 2006, p. 75).

${ }^{5}$ Esse foi um dos navios portugueses que ficaram no Brasil para uso do Império. Segundo ofício publicado no Livro Alexandre José de Mello Morais (Morais, 2004, p. 295-296).

${ }^{6}$ Luiz Geraldo da Silva aponta três motivos para a adesão do grupo federalista: o fracasso das cortes em garantir os direitos federativos das províncias do Brasil, em segundo lugar a aceitação das camadas populares, notadamente os militares pretos e pardos a adesão ao projeto do Rio de Janeiro e em terceiro o fato do príncipe acenar para uma proposta constitucional (Silva, 2008, p. 208).

${ }^{7}$ A situação ficou complicada na virada do ano, quando segundo o periódico a Gazeta Pernambucana, de 25 de março de 1823 em primeiro de janeiro de 1823 mandou prender cento e oitenta europeus que foram soltos no dia seguinte devido a ação de mais de cinquenta rapazes a favor dos presos. Em 6 de janeiro ele foi deposto em parte pelos seus desvarios e em parte pelas demonstrações de afeto das camadas populares sendo reintegrado no mesmo dia devido a ação de uma comissão de militares negros. Em 8 de janeiro saiu pelas ruas com uma multidão de pardos e pretos, "quase todos esfarrapados, ébrios e descalços" gritando contra o Governo e que não devia se dar entrada para o novo Governador das Armas enviado pelo Imperador.

${ }^{8}$ Instituído como de Grande Gala pelo decreto de 21 de dezembro de 1822. Esse decreto definiu os dias de gala do país. Ver (Santos, 2011, p. 60 a 63). 